International Journal of Business Management and Economic Review

Vol. 4, No. 06; 2021

ISSN: 2581-4664

\title{
THE INFLUENCE OF HUMAN RESOURCE QUALITY, THE INTERNAL CONTROL SYSTEM AND THE UNDERSTANDING OF THE GOVERNMENT ACCOUNTING STANDARD ON THE PROCESS OF FINANCIAL REPORT PREPARATION
} (A Study at the Regency Service Unit (SKPK) of Aceh Singkil Regency)

\author{
Aulia Rahman, Aliamin and Muslim A Djalil* \\ Faculty of Economics and Business, Universitas Syiah Kuala \\ http://doi.org/10.35409/IJBMER.2021.3328
}

\begin{abstract}
This object of study is to determine the effect of the quality of human resource, the internal control system and the understanding of government accounting standard on the process of preparing financial report in Aceh Singkil Regency Service Unit (SKPK). The population of the research is 46 Units of SKPK and the respondents are 46 Financial Administration Officials (PPK) of each SKPK. The collected data are analyzed by using multiple linear regression equation with SPSS Version 23.0 software. The research results indicated that the quality of human resource, internal control system, and the understanding of government accounting standard have a significant influence on the process of preparing financial reports of SKPK in the regency both simultaneously and partially.
\end{abstract}

Keyword: Quality of Human Resource, Internal Control System, Understanding of Government Accounting Standard, Financial Statement Preparation Process.

\section{INTRODUCTION}

Public openness and accountability are a demand in this era of government financial reform. For this reason, each work unit, including the local governments must be accountable for the local finance in the transparent manner to the public, which is actualized in the form of Financial Reports of Local Government (LKPD). With the issuance of Law No. 22 of 1999 concerning Local Government and Law No. 25 of 1999 concerning the Financial Balance between the State and the Local Governments, the centralized government system had been changed into the decentralized government system. It is hoped that each region will be more efficient and effective in regulating the development process since it has been delegated its own powers and freedoms to regulate important policies for the improvement and independence of each regions.

One type of local government accountability in carrying out and actualizing the local improvement is the Local Financial Reports, in which as the implementer of autonomy and financial management, the Local Government have to submit financial reports on the implementation of the "State Budget/Provincial Budget" or APBN/APBD (Law No. 17 of 2003).

Financial report is a form of accountability on the economic resources management owned by an entity. The published financial reports must be prepared in accordance with the accounting standards that relevant as of the moment so that it can be compared with the financial statements of the previous period or can be compared with the other entities (Ihsanti, 2014). In order to create 


\section{International Journal of Business Management and Economic Review}

Vol. 4, No. 06; 2021

ISSN: 2581-4664

a realization of a good governance in the administration and management of state government, the Government Financial Management Reform was initiated several years ago, which was covered by Law No. 17 of 2003 on State Finance, Law No. 1 of 2004 concerning the State Treasury, and Law No. 15 of 2004 concerning the audits of the State Financial Management and Responsibility.

Similarly, the Aceh Singkil Regency, which annually must be accountable for its performance through financial reports, the financial reports of this regency are very much determined by the financial reports of each Regency Service Units (SKPK). Therefore, the SKPK's financial report preparation process calculated on the basis of preparing the local financial report.

In his research, Ihsanti (2014) states that financial report is a product generated by the accounting field or discipline. Therefore, competent Human Resources (HR) are needed to produce an excellence financial report. Human Resource Competency is the ability of a person or individual in an organization (institution) or a system to carry out their functions or authority in order to effectively and efficiently achieve their goals.

In addition to human resource capacity, the SKPK's financial report is also influenced by understanding the government accounting standards and the government internal control systems. The results of the inspectorate review of SKPK's financial reports in the Aceh Singkil Regency shows the bare minimum and weak application of the Government Accounting Standard and the Government Internal Control Systems to financial reports in each SKPK. According to Udiyanti (2014), the government accounting standard is the accounting principles that established in preparing and presenting the government financial reports. The purpose of implementing this standard is so that the financial reports can improve the quality of the state and regional governments' financial reports.

The financial report of the Local Government (Pemda) is prepared based on the internal control system (SPI) as mandated in Article 56 paragraph (4) of Law No. 01 of 2004 which stated that the head of the local organization as users of the budget/users of goods provide a statement that the management of the APBD in the workplace environment has been organized based on an adequate internal control system and the financial reports based on the government accounting standards. To improve performance, transparency, and accountability in the management of the State Finance, it is necessary to implement the SPI (Herawati, 2014).

The results of the Inspectorate Review of Aceh Singkil Regency in 2018 show that the implementation of the Internal Control System in the preparation of LK-SKPK and LKPK is ineffective and inefficient and did not compliant with the rules, in which the delegation of authority and responsibility are incorrect. In consequence, it affects the timeliness of preparing and submitting the reports as well as the execution of the accounting system.

In addition, the phenomenon that occurs illustrate the low quality of the Financial Report Preparation Process in each SKPK in Aceh Singkil Regency, where so far the submission of financial reports in each SKPK is still experiencing delays or not according to the schedule set by the government (Permendagri No. 13 of 2006, article 295 paragraph 1: the SKPK financial reports as referred to in Article 294 paragraph (1) are submitted to the heads of local governments through the PPKK no later than 2 (two) months after the fiscal year ends), resulting in delays in the report preparation process of the Local Financial Report, as well as the weak implementation of an accounting system that based on the government accounting system in each SKPK.

Research conducted by Sudiarianti (2015) states that in addition to human resource competency, the implementation of SAP (Government Accounting Standard) through an effective 
internal control by competent employees will produce reliable financial reports. The SAP requires each reporting entities, including the local governments to report and inform the efforts that have been done and the results achieved in the implementation of a systematic and structured activities in one period of reporting for accountability, management, transparency, balance between generation and evaluation. The implementation of SAP by the local government will produce a good quality financial reports that contains useful information.

\section{LITERATURE REVIEW}

\section{The Process of Financial Report Preparation}

The process of preparing financial reports is a process of recording the financial information of an organization or company during an accounting period that can be used to describe the performance of the organization or company. Good or bad financial statements of an organization are also determined by the process in its preparation, since there are several criteria that must be met in a financial report.

The government financial reporting phenomenon in Indonesia is something interesting to observe. From various studies that have been successfully downloaded from the internet, it turns out that there are still many inconsistent data presented in the government financial reports (Yendrawati, 2013).

\section{Human Resources (HR)}

There are several factors that affect the quality in the preparation of financial reports, namely good government and the quality of human resources in the process of preparing financial reports. According to Amran (2009), HR is one of the factors that determine the success of an institution. A good quality and professional human resources will certainly be able to affect the quality of accounting information in an entity's financial statement presentation (Made \& Anggreni, 2018).

In some literatures, it is stated that there are several aspects of human resources management that must be considered and cannot be ignored, since it's important for human resource development. According to Dharma $(1985 ; 12)$ in Widodo $(2015)$, there are several aspects in the development of human resources that must be noted, among others:

1. Analysis

2. Planning

3. Education and training

4. The Implementation of employee duties

5. Incentives

6. Performance appraisal

\section{Understanding the Government Accounting Standard}

An understanding of SAP is indispensable in preparing financial reports because in every implementation of an entity's activities, in this case the government, is obliged to report the efforts that have been made systematically and structured for the purposes of accountability, management, and transparency of activities within an entity or government. According to Adhi (2013), with the application of SAP, a financial report can be prepared in a way that is easy to be used by diverse parties, especially by the auditorial team. The financial report itself is determined from the amount 


\section{International Journal of Business Management and Economic Review}

Vol. 4, No. 06; 2021

ISSN: 2581-4664

of information provided within the content. Therefore, should an entity wish to obtain a quality financial report, it must be prepared based on SAP.

In order to understand the SAP, the local financial managers, in this case the editors of the financial reports, must first understand the accounting principles and the financial reporting principles, in which the principles of accounting and the local financial reporting refer to the Government Regulation No. 71 of 2010, Annex II.02 the Statement of the Government Accounting Standard (PSAP) No. 1 concerning the Presentation of the Financial Reports.

\section{The Internal Control System}

The achievement of an institution's objectives is based on the government internal control system (SPIP) through a continuous process that is indivisible from an action and activity by an employer to all employees so as to provide assurance in order to carry out all activities effectively and efficiently. By doing so, the financial reporting that will be presented becomes reliable. The internal control system itself, based on the Government Regulation No. 60 of 2008, is a process that is influenced by the HR and the information technology systems that designed to assist an organization in achieving its objectives.

The factor that affect the quality of financial reporting is the SPIP, which compiles of the five components that based on the Government Regulation (PP) No. 60 of 2008: (1) the control environment; (2) the risk assessment; (3) the control activities; (4) the information and communication; and (5) the monitoring (Siwambudi, et.al, 2017).

\section{RESEARCH METHOD Research Design}

Research design is a plan and research organization that is structured in such a way so the researcher will be able to obtain answers to the researcher's questions. The descriptive quantitative was employed in this study. It was actualized by means of searching for information on the prior indicators, defining the objectives, planning the approach, and gathering the data for the report. The research was carried out in each SKPK of Aceh Singkil Regency.

1. Study Objectives

The aims of the study are to determine the nature and relationship between variables in hypothesis testing as well as to determine the effect of the independent variables on the dependent variable.

2. Types of Investigation

The study is based on the correlational research. It's a research which is constructed on the premise of finding the most important variables that related to a problem (Sekaran, 2011). In this study, the researcher wanted to see the effect of the quality of human resources, the Internal Control System (SPI) and the Understanding of Government Accounting Standards (SAP) on the process of preparing the SKPD's financial reports in the Aceh Singkil Regency.

3. Researcher's Intervention Level

In order to determine the results of the research, the researchers do not manipulate nor intervene in any kind of ways. This research is a field study, a study that was conducted with the intention of finding out the causal relationships through a similar natural environment.

4. Unit of Analysis

The analysis unit used in this study is an institution/organization, which is all the Local Work 
International Journal of Business Management and Economic Review

Vol. 4, No. 06; 2021

ISSN: 2581-4664

Units of Aceh Singkil Regency.

5. Time Horizon

The time used in the data collection is cross sectional. It means that several variables can be measured at the same time or the data can be collected at the same time.

\section{The Sources and the Data Collection Techniques}

The primary data are obtained by directly distributing the questionnaires to 46 respondents out of the total population.

\section{METHOD OF ANALYSIS}

The quantitative method is used to analyze the data in this research. The data that have been acquired through a questionnaire is modified into the quantitative data before being analyzed by the SPSS (Statistical Package for Social Science) program. The linear regression analysis is the analysis method used in this study based on the formula below:

$$
\mathbf{Y}=\boldsymbol{\alpha}+\boldsymbol{\beta}_{1} \mathbf{X}_{1}+\boldsymbol{\beta}_{2} \mathbf{X}_{2}+\boldsymbol{\beta}_{3} \mathbf{X}_{3}+\mathrm{e}
$$

$\mathrm{Y}=$ Financial Reports Preparation Process

$\mathrm{X}_{1}=$ The quality of Human Resources

$\mathrm{X}_{2}=$ The Application of the Internal Control System

$\mathrm{X}_{3}=$ Understanding the Government Accounting Standards

$\alpha=$ Constant

$\beta=$ the coefficient (beta) value

$\mathrm{e}=$ margin of error

\section{RESULTS AND DISCUSSIONS}

\section{Results}

\section{Descriptive Analysis}

Descriptive analysis is a description of the respondents' frequency in answering the statements contained in the questionnaire about the research variables, namely the process of preparing financial reports $(\mathrm{Y})$, the quality of human resources (X1), the internal control systems (X2), and understanding the government accounting standards (X3).

Descriptive statistic is useful in providing an overview or description of the variables used in this study. The following is the descriptive statistical value of each research variable as shown on the Table 1 below:

\section{Table 1. Descriptive Statistics}

\begin{tabular}{|l|l|l|l|l|l|}
\hline & $\mathrm{N}$ & Min & Max & Mean & Std. Deviation \\
\hline $\begin{array}{l}\text { Preparation } \\
\text { of financial } \\
\text { reports }\end{array}$ & 46 & 3.63 & 5.00 & 4.08 & .362 \\
$\begin{array}{l}\text { The quality } \\
\text { of human }\end{array}$ & 46 & 3.00 & 4.55 & 3.94 & .390 \\
\hline
\end{tabular}


Vol. 4, No. 06; 2021

ISSN: 2581-4664

\begin{tabular}{|l|l|l|l|l|l|l|}
\hline \hline resources & & 46 & 2.93 & 4.93 & 3.89 & .522 \\
SPIP & 46 & 3.42 & 5.00 & 4.09 & .442 \\
SAP & 46 & & \\
$\begin{array}{l}\text { Valid N } \\
\text { (listwise) }\end{array}$ & 46 & & \\
\hline
\end{tabular}

Table 1 above illustrates the minimum, the maximum, the average and the standard deviation values of the variables. The SKPD report preparation process variable obtained the minimum value at 3.63 , the maximum value is 5.00 , and the average value is 4.08 with the standard deviation of 0.362 . The HR quality variable stands at the minimum value of 3.00 , the maximum value of 4.55 , and the average value of 3.94 with a standard deviation of 0.390 . For the internal control system variable, the minimum value charge at 2.93 , the maximum value $=4.93$, and the average value $=$ 3.89 with a standard deviation $=0.522$. Meanwhile, the last variable government accounting standard_has a minimum value of 3.42, a maximum value of 5.00, and an average value of 4.09 with a standard deviation of 0.442 .

\section{The Hypothesis Testing Results}

The hypothesis testing was utilized by using the multiple regression analysis. The SPSS program was also used to simplify the process of data analysis. This analysis aims to find the relationship between the dependent variable and one or more independent variables. The results of hypothesis testing can be seen in the table 2 below:

Table 2. The Hypothesis Testing Results

\begin{tabular}{|l|l|l|l|}
\hline Variable & $\mathrm{B}$ & $\mathrm{t}$ & Sig. \\
\hline (Constant) & 1.431 & 3.27 & 0.002 \\
\hline $\begin{array}{l}\text { The Quality of } \\
\text { Human } \\
\text { Resources }\end{array}$ & 0.208 & 1.66 & 0.104 \\
\hline $\begin{array}{l}\text { The Internal } \\
\text { Control System }\end{array}$ & 0.100 & 0.76 & 0.451 \\
\hline $\begin{array}{l}\text { Understanding } \\
\text { the Government } \\
\text { Accounting } \\
\text { Standards }\end{array}$ & 0.352 & 2.07 & 0.044 \\
\hline \multicolumn{3}{|l|}{} \\
\hline
\end{tabular}

Based on the results of the regression test above, it can be formulated the multiple linear 
International Journal of Business Management and Economic Review

Vol. 4, No. 06; 2021

ISSN: 2581-4664

regression equation as follows:

$Y=1,431+0,208 X_{1}+0,100 X_{2}+0,352 X_{3}+e$

Discussions

The Quality of Human Resources

The results show that the quality of human resources had an effect on the financial reporting process. The regression coefficient $\left(\beta_{1}\right)$ is 0.208 , indicating that each increase in the quality of human resources by 1 interval will be followed by an increase in the SKPD's financial report preparation process by 0.208 interval. This result indicates a positive relationship between the quality of human resources with the SKP's financial reporting process. It can be said that the higher the quality of the human resources, who're in charge of preparing of the SKPD's financial reports, the better the preparation process of the SKPD's financial report in the Aceh Singkil Regency.

\section{The Internal Control System}

The results show that the internal control system had an effect on the financial reporting process. The coefficient value $\left(\beta_{2}\right)$ is 0.100 , indicating that each increase in the internal control system by 1 interval will be followed by an increase in the financial report preparation process by 0.100 interval. This means that the better the implementation of the internal control system in an institution, the better the improvement of the quality of the SKPD's financial reporting process.

\section{Understanding the Government Accounting Standards}

The results show that understanding the government accounting standards has an effect on the process of preparing financial reports. The regression coefficient value $\left(\beta_{3}\right)$ is 0.352 , indicating that every increase in understanding the government accounting standards by 1 interval will be followed by an increase in the financial statement preparation process by 0.352 interval. It means that a better understanding of the government accounting standards gives a higher chance of a much better quality of the financial reporting process.

\section{CONCLUSIONS, LIMITATIONS, RECOMMENDATIONS Conclusion}

The quality of human resources, the internal control system and understanding the government accounting standard have a significant influence on the SKPD's financial reporting process in the Aceh Singkil Regency, either simultaneously or partially. This indicates that the better the quality of human resources, the internal control system and understanding the government accounting standards, the better the SKPD's financial reporting process.

\section{Limitations}

1. The data used in this study were gathered using questionnaire items adopted and expanded from previous research.

2. Since some of the questionnaires were distributed by using an online application of Google Form therefore some interactions between the respondents and the researchers were indirect (not face-to-face interaction).

\section{Recommendations}




\section{International Journal of Business Management and Economic Review}

Vol. 4, No. 06; 2021

ISSN: 2581-4664

1. It is suggested that heads of the SKPK in the Regency to provide an adequate competency training for staff on the preparation and analysis of the financial report. Furthermore, to provide opportunities for the employees to continue their education to the next level hence helping them in developing a better understanding of a good financial reports preparation process.

2. Future research may add or replace the independent variables, such as the application of the local financial management information system, leadership style, or other factors that may affect the SKPK's financial reporting process.

\section{REFERENCES}

Adhi, D. K., \& Suhardjo, Y. (2013). Pengaruh Penerapan Standar Akuntansi Pemerintahan dan Kualitas Aparatur Pemerintah Daerah terhadap kualitas laporan keuangan (studi kasus pada pemerintah kota Tual). Jurnal STIE Semarang, 5(3), 93-111.

Anggreni, N. M. M., Widanaputra, A. A. G. P., \& Putri, I. G. A. D. (2018). Pengaruh Good Governance dan Kompetensi Sumber Daya Manusia Pada Kualitas Laporan Keuangan Di Kota Denpasar. E-Jurnal Akuntansi, 352-380.

Herawati, T. (2014). Pengaruh Sistem Pengendalian Intern Terhadap Kualitas Laporan Keuangan (Survei Pada Organisasi Perangkat Daerah Pemda Cianjur). STAR-Study \& Accounting Research, 11(1), 1-14.

Ihsanti, E. (2014). Pengaruh kompetensi sumber daya manusia dan penerapan sistem akuntansi keuangan daerah terhadap kualitas laporan keuangan daerah (studi empiris pada SKPD Kab. Lima Puluh Kota). Jurnal Akuntansi, 2(3).

Siwambudi, I. G. N., Yasa, G. W., \& Badera, I. D. N. (2017). Kompetensi Sdm Dan Sistem Pengendalian Intern Pada Kualitas Laporan Keuangan Fakultas Ekonomi dan Bisnis Universitas Udayana ( Unud ), Bali, Indonesia Pendahuluan Tuntutan pelaksanaan akuntabilitas sektor publik terhadap terwujudnya good governance di Indonesia, 1, 385-416.

Sekaran, U. (2011). Metode Penelitian Untuk Bisnis (Research Methods For Business). (Edisi 4). Jakarta: Salembat Empat.

Sudiarianti, N. M., Ulupui, I. G. K. A., \& Budiasih, I. G. A. (2015). Pengaruh Kompetensi Sumber Daya Manusia Pada Penerapan Sistem Pengendalian Intern Pemerintah dan Standar Akuntansi Pemerintah Serta Implikasinya Pada Kualitas Laporan Keuangan Daerah. Simposium Nasional Akuntansi XVIII.

Undang-undang Nomor 17 Tahun 2003 tentang Keuangan Negara.

Widodo, W. (2015). Pengaruh Sumber Daya Manusia Terhadap Kemampuan Kerja Pegawai (Studi di Sekretariat Daerah Kabupaten Lampung Timur). Jurnal Tapis: Jurnal Teropong Aspirasi Politik Islam, 11(2), 116-128. 